Vol. 17 (2008): 88-101.

\title{
Effect of cropping system and peat amendment on strawberry growth and yield
}

\author{
Mauritz Vestberg, Sanna Kukkonen, Hanna Kuru, Kaisa Saari \\ MTT Agrifood Research Finland, Plant Production Research, Horticulture, FI-41330 Vihtavuori, Finland, \\ email: mauritz.vestberg@mtt.fi \\ Timo Hurme \\ MTT Agrifood Research Finland, Services Unit, Information Management, FI-31600 Jokioinen, Finland
}

\begin{abstract}
Comparative studies have usually shown higher yields in conventional cropping systems (CCS) than in organic cropping systems (OCS). By utilizing a long-term field experiment on silt soil with 18 years of cropping history (1982-1999), including three OCSs and one CCS, we studied if this is true also for strawberry. The strawberry experiment was conducted in 2000-2002. The experiment had one CCS (A) and three OCSs (B,C,D). The impact of pre-planting peat amendment was also studied. The degree of overwintering, fruit yields, yield components and some soil nutrients were determined. Total and marketable fruit yields were estimated using a peduncle analysis based on weights of fruits of different orders in the peduncle, numbers of healthy and injured fruits in the peduncle and the number of peduncles per plant. The shoot growth, total and marketable fruit yields, as well as all yield components estimated were significantly higher in the OCS rotation D than in the CCS rotation A. The peat amendment, but not the cropping system, decreased the percentage of strawberry plants suffering from or killed by winter damage. However, peat amendment did not affect yield. The cropping system had no impact on soil $\mathrm{pH}$, or the amount of extractable calcium, magnesium and nitrate. Extractable phosphorus and potassium were higher and soil organic carbon $\left(\mathrm{C}_{\mathrm{org}}\right)$ slightly higher in the OCS than in the CCS. The peat amendment increased $\mathrm{C}_{\text {org }}$ by $2 \%$. The amounts of extractable nutrients in soil were not a limiting factor for strawberry growth and yield as they were of sufficient levels both in CCS and OCS. It remains unclear whether the higher yield in the OCS was due to a long-term cropping history or to a short-term effect of composted manure, or to a combination of these two. The importance of soil organic management in strawberry production is emphasized.
\end{abstract}

Keywords: conventional cropping system, marketable yield, organic cropping system, peat amendment, soil properties, strawberry, total yield, yield components 
Vol. 17 (2008): 88-101.

\section{Introduction}

Several reviews of yield and profitability in organic cropping systems (OCS) and conventional cropping systems (CCS) have been carried out (Stanhill 1990). On average, the yield levels in OCSs have been slightly to moderately lower than in CCSs, but the agricultural intensity and crop can affect this difference dramatically. In areas of intense conventional agriculture, such as central and northern Europe, the difference in yields between OCSs and CCSs can be considerable and reach $50 \%$ or more (Korva and Varis 1990, Mäder et al. 2002, Gesslein 2001).

In strawberry production, the yield levels obtained in organic and conventional cropping systems follow much the same lines as agricultural crops (Rhainds et al. 2002, Gliessman et al. 1996). Gliessman et al. (1996) compared various parameters of strawberry growth and reproduction in a three-year on-farm study in a conventional production system and in a system undergoing conversion to organic management. The yield of marketable fruit was consistently lower on the organic plots, but the difference decreased from $39 \%$ to $28 \%$ over the course of the study. However, they also concluded that market conditions resulted in greater returns per hectare in the organic production system. The difficulty in controlling grey mould (Botrytis cinerea Pers.) is probably one of the main reasons for lower yield levels in organic than in conventional strawberry production. In organic strawberry production, $B$. cinerea can be controlled only by cultural methods like cultivar resistance, planting time, defoliation, etc., but none of these methods is capable of providing satisfactory control over this disease (Daugaard 1999).

At present there is much concern about the loss of soil organic carbon $\left(\mathrm{C}_{\text {org }}\right)$ throughout the world. Long-term studies have shown that continuous cropping results in a decline of $\mathrm{C}_{\text {org }}$, although the rate and magnitude of the decline is climate- and soil-dependent and can be ameliorated by wise soil management practices (Reeves 1997). Management practices that positively affect $\mathrm{C}_{\text {org }}$ include the use of deep-rooted and perennial plants, manure and composts and other organic materials. For exam- ple, partly decayed Sphagnum peat has been used as a rapid way of increasing $\mathrm{C}_{\text {org }}$ on heavy (Kytö et al. 1983, Pietola and Tanni 2003) and sandy soil (Li et al. 2004). Pietola and Tanni (2003) found that plant growth was enhanced even five years after peat application.

In a long-term field experiment with contrasting cropping histories (conventional vs. low input/ organic cropping system) we found higher levels and activities of several biological soil properties in the OCS than in the CCS after 17 years (Vestberg et al. 2002). At the same time, the amounts of extractable mineral nutrients in the soil tended to be lower in the organic rotations than in the conventional rotations. Utilizing the same long-term field experiment, we now ask whether these differences in soil properties are reflected also in growth, yield and yield components of the subsequent perennial strawberry. Since the study area has very low $\mathrm{C}_{\text {org }}$ we also studied whether peat amendment would increase $\mathrm{C}_{\text {org }}$ and affect strawberry yields in the short term.

\section{Material and methods}

\section{Field experiment}

\section{Experimental design 1982-1999}

A long-term field experiment to compare CCS with low-input cropping system was established on silt soil in 1982 at MTT Agrifood Research Finland, Laukaa, Finland. The soil had a high mean $\mathrm{pH}$ (7.1), but the organic carbon $\left(\mathrm{C}_{\text {org }}\right)$ content was low, $1.36 \%$. At establishment, the amounts of acid ammonium acetate-extractable phosphorus (P), potassium $(\mathrm{K})$, calcium $(\mathrm{Ca})$ and magnesium $(\mathrm{Mg})$ were $30,84,2156$ and $266 \mathrm{mg} \mathrm{l}^{-1}$ soil, respectively. These values represent, according to the interpretation of soil test results (Viljavuuspalvelu Oy 2000), a good status for $\mathrm{P}, \mathrm{Ca}$ and $\mathrm{Mg}$, but a fair status for $\mathrm{K}$. The experiment consisted of 36 plots arranged in three complete blocks ( 3 blocks $\times 4$ sub-plots $\times$ 3 main plots $)$ with a plot size of $50 \mathrm{~m}^{2}(5 \mathrm{~m} \times 10 \mathrm{~m}$; width $\times$ length). Each block included four rotations 
Vestberg, et al. Cropping system impact on strawberry fruit yield

A, B, C and D (i.e. four levels of the subplot factor) that were repeated three times (three levels of the main plot factor, starting points 1-3) by starting a rotation from years 2, 4 and 5 (Fig. 1). Each rotation lasted for 6 years. A and B were CCS rotations fertilized with full (rotation A) or half (rotation B) the recommended amounts of mineral fertilizers. $C$ and $\mathrm{D}$ were low-input rotations resembling those used in organic agriculture. In rotation $\mathrm{C}$, crop residues were returned to the plot as such, but in rotation $\mathrm{D}$ the crop residues were composted. For more details about rotations and fertilization, see Vestberg et al. (2002).
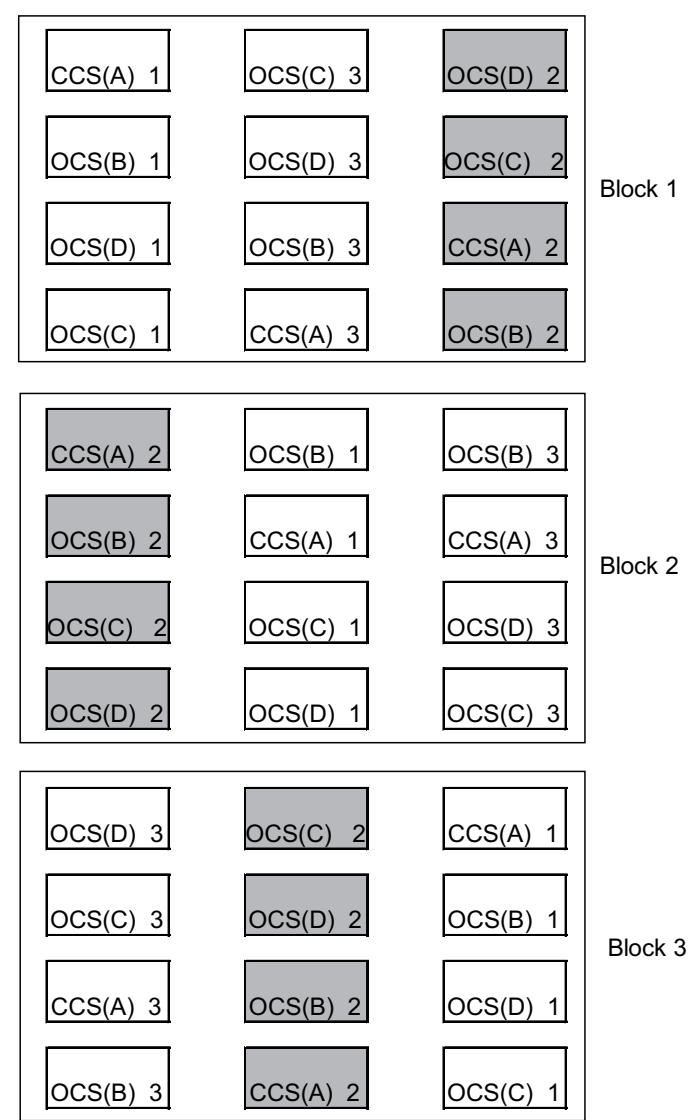

Fig. 1. Experimental design. $\mathrm{CCS}=$ conventional cropping system, $\mathrm{OCS}=$ organic cropping system, $A-D=$ crop rotations, $1-3=$ rotation starting points. Plots marked in grey were peat-amended prior to planting of strawberry in 2000.
In 1994, the CCS rotation B and the low-input rotations $\mathrm{C}$ and $\mathrm{D}$ were changed into transitional stage of organic farming, while rotation A continued as a pure cereal CCS rotation. By 1999, rotations B - D were organic cropping system (OCS) rotations. Rotations $\mathrm{B}$ and $\mathrm{C}$ included three successive years of ley, while rotation D had two successive years of ley at the most. Leys and rye were given $15 \mathrm{t} \mathrm{ha}^{-1}$ composted animal manure in the year of establishment before 1997. Thereafter the amount was doubled to $30 \mathrm{t} \mathrm{ha}^{-1}$ (see Vestberg et al. 2002).

\section{Experimental design 2000-2002}

During 2000-2002, strawberry was grown in the whole experimental area. Cropping systems were continued as CCSs (rotation A) and OCSs (rotations B, C, D). At establishment in 2000, plots A were fertilized according to the soil analysis with $300 \mathrm{~kg} \mathrm{ha}^{-1}$ compound solid fertilizers "Puutarhan yleislannos" (8N-4P-14K, Kemira GrowHow, Finland) and $500 \mathrm{~kg} \mathrm{ha}^{-1}$ "Puutarhan PK-lannos" (2N-5P-18K, Kemira GrowHow, Finland) (Table 1). The OCS rotations B, C and D were fertilized with local composted farmyard manure (FYM, $20.2 \%$ dry weight, $0.5 \mathrm{~kg}$ extractable $\mathrm{N}, 4.7 \mathrm{~kg}$ total $\mathrm{N}, 1.5 \mathrm{~kg}$ total $\mathrm{P}$ and $3.0 \mathrm{~kg}$ total $\mathrm{K}$ per ton fresh FYM, respectively, analyzed by Novalab Oy, Finland). The plots that had clover as the preceding crop in 1999 and the plots that received FYM in 1998 - 1999 were given 25 tons per ha FYM, while the plots with a cereal as the preceding crop were given 50 tons (Table 1).

Before making the strawberry beds, starting point 2 of each rotation was amended with $500 \mathrm{~m}^{3}$ ha $^{-1}$ well humified natural Sphagnum peat $(\mathrm{pH} 4$, H 4-7 on the von Post scale (von Post 1922), Vapo Oy, Finland). The peat was incorporated into the uppermost $20 \mathrm{~cm}$ of the soil using a rotary harrow. The rotation starting points designated as 1 and 3 in rotations A-D were left unamended.

In the middle of June 2000, micropropagated strawberry (Fragaria $\times$ ananassa) 'Senga Sengana' plants were planted in raised beds (one bed per experimental plot, plants $33 \mathrm{~cm}$ apart, making a total of 30 plants per bed) mulched with black plastic. The area was equipped with an irrigation 
Vol. 17 (2008): 88-101.

Table 1. Fertilization and fertigation for different rotations during the experiment. Letters A, B, C and D refer to rotations A - D. Numbers 1, 2 and 3 refer to starting point of rotation.

\begin{tabular}{|c|c|c|c|c|c|c|}
\hline \multicolumn{2}{|c|}{ Rotation } & \multirow[b]{2}{*}{ Year } & \multirow[b]{2}{*}{$\begin{array}{l}\text { Type of fertiliza- } \\
\text { tion given }\end{array}$} & \multicolumn{3}{|c|}{$\begin{array}{l}\text { Amount of } \mathrm{N}, \mathrm{P} \text { and } \mathrm{K} \text { applied, } \\
\mathrm{kg} \mathrm{ha}^{-1}\end{array}$} \\
\hline Code & Type of rotation & & & $\mathrm{N}$ & $\mathrm{P}$ & $\mathrm{K}$ \\
\hline $\mathrm{A} 1, \mathrm{~A} 2, \mathrm{~A} 3$ & Conventional & 2000 & $\begin{array}{l}\text { Compound, } \\
\text { solid, by } \\
\text { broadcasting }\end{array}$ & 28 & 40 & 150 \\
\hline “ & “ & 2001 & Fertigation & 30 & 11 & 45 \\
\hline “ & “ & 2002 & “ & 30 & 11 & 45 \\
\hline $\mathrm{B} 1, \mathrm{~B} 2, \mathrm{~B} 3$ & Organic & 2000 & FYM $^{1)}$ & 117.5 & 37.5 & 75 \\
\hline “ & “ & 2001 & None & - & - & - \\
\hline “ & “ & 2002 & None & - & - & - \\
\hline $\mathrm{C} 1, \mathrm{C} 2, \mathrm{C} 3$ & Organic & 2000 & FYM & 117.5 & 37.5 & 75 \\
\hline “ & “ & 2001 & None & - & - & - \\
\hline “ & “ & 2002 & None & - & - & - \\
\hline D1, D2 & Organic & 2000 & FYM & 117.5 & 37.5 & 75 \\
\hline “ & “ & 2001 & None & - & - & \\
\hline “" & “ & 2002 & None & - & - & \\
\hline D3 & “ & 2000 & FYM & 235 & 75 & 150 \\
\hline “ & “ & 2001 & None & - & - & - \\
\hline “ & “ & 2002 & None & - & - & - \\
\hline
\end{tabular}

${ }^{1)}$ Farmyard manure

and fertigation system (T-tape, Hortimic, Finland) to keep the soil water potential at optimal levels for strawberry growth. In 2000, only water was given through the system. In 2001 and 2002, the CCS rotation A was fertigated while the OCS rotations B-D were only irrigated. The need for irrigation was determined using tensiometers (Jet Fill Tensiometer, Soil Moisture Equipment Corp., USA) placed in the strawberry beds at a depth of $20 \mathrm{~cm}$ at three locations in the area. Irrigation was started at $-500 \mathrm{hPa}$ soil water potential. Rotation A was fertigated using a $0.3 \%$ solution of "Puutarhan täyslannos" (14N-5P-21K, Kemira GrowHow, Finland) (Table 1). Fertigation was given five times during the growing season. During early strawberry growth, $25 \%$ of the yearly amount was given. On ripening of the first fruits, $17 \%$ was given, followed by further applications of the same amount one and two weeks later. The remaining $25 \%$ of the total amount of nutrients was given immediately after the fruiting season.

\section{Plant and soil analyses}

\section{Plant overwintering and vegetative growth}

The degree of damage on each plant was estimated in May 2001 and 2002 on a scale from 0 to $2(0=$ dead, $1=$ injured, $2=$ no damage $)$ and the percentage of damaged (dead + injured) plants in each experimental plot was calculated. To determine 
Vestberg, et al. Cropping system impact on strawberry fruit yield

the aboveground vegetative biomass, five randomly chosen plants per plot were cut, dried $(24 \mathrm{~h}$ at $105^{\circ} \mathrm{C}$ ) and weighed.

\section{Fruit yield}

Strawberry fruit yields were estimated in 2001 and 2002 using a peduncle analysis method (Tuovinen and Parikka 1997). At the time of ripening of the first fruits in early July, all peduncles of five randomly chosen plants per plot were cut off and the numbers of ripe and unripe fruits of different hierarchial orders $\left(1^{\text {st }}, 2^{\text {nd }}\right.$ and $3^{\text {rd }}$ orders $)$ were counted. The numbers of injured fruits were also recorded, as well as the number of peduncles per plant. The mean weights of ripe, healthy fruits of each of the orders 1-3 were estimated from 40-50 fruits per plot at the time when fruits of these orders had ripened in the field. The estimated total fruit yield per plant was calculated from the following formula:

Yield $_{T O T}=\left(1 \mathrm{~A}_{\mathrm{nr}} \times 1 \mathrm{~A}_{\mathrm{FW}}\right)+\left(2 \mathrm{~A}_{\mathrm{nr}} \times 2 \mathrm{~A}_{\mathrm{FW}}\right)+\left(3 \mathrm{~A}_{\mathrm{nr}}\right.$ $\left.\times 3 \mathrm{~A}_{\mathrm{FW}}\right)$,

where $1 A_{n r}, 2 A_{n r}$ and $3 A_{n r}$ are the total number of fruits of $1^{\text {st }}, 2^{\text {nd }}$ and $3^{\text {rd }}$ order, respectively, in the peduncle and $1 A_{F W}, 2 A_{F W}$, and $3 A_{F W}$ are the total fresh weights $(\mathrm{FW})$ of fruits of $1^{\mathrm{st}}, 2^{\text {nd }}$ and $3^{\text {rd }}$ order, respectively, in the peduncle.

To estimate the marketable yield, a similar formula was applied in which only the healthy fruits were considered.

\section{Soil analyses}

Soil chemical analyses were done only for the contrasting cropping systems A and D. In 2001, soil samples were collected in September after the growing season for determination of extractable nutrients $\left(\mathrm{NO}_{3}-\mathrm{N}, \mathrm{NH}_{4}-\mathrm{N}, \mathrm{P}, \mathrm{K}, \mathrm{Ca}, \mathrm{Mg}\right), \mathrm{pH}$ and electrical conductivity (EC). Using a $2 \mathrm{~cm}$ soil borer, 10 sub-samples were collected from the uppermost $20 \mathrm{~cm}$ of each plot and pooled and mixed thoroughly. The amounts of soluble NO. $-\mathrm{N}$ and $\mathrm{NH}_{4}-\mathrm{N}$ were determined from frozen soil by extraction in a $2 \mathrm{M} \mathrm{KCL}$ solution (soil:extract solution 1:2.5). The amounts of soluble $\mathrm{P}, \mathrm{K}, \mathrm{Ca}$ and $\mathrm{Mg}$ were determined from acid ( $\mathrm{pH} 4.65)$ ammonium acetate $(0.5 \mathrm{M}$ acetic acid, $0.5 \mathrm{M}$ ammonium acetate) soil extract. The soil $\mathrm{pH}$ and $\mathrm{EC}$ were measured from a soil-water suspension, 1:2.5 $(\mathrm{v} / \mathrm{v})$. The soil organic $\mathrm{C}\left(\mathrm{C}_{\text {org }} \%\right)$ was determined using a LECO CN-2000 analyser.

\section{Statistical methods}

The overwintering and yield parameters, excluding shoot dry weight (DW), were analyzed as a split-plot design with repeated measures. In the analyses, rotation starting point was considered as a whole-plot factor, cropping system as a subplot factor, year as a repeated measure and replication as a blocking factor. Repeated measurements from the same experimental plot were correlated, which was taken into account in the statistical models through covariance structures. Compound symmetry was found to be appropriate structure for all models. Thus, the linear model could be formulated as:

$Y_{i j k l}=\mu+b_{i}+s_{j}+\varepsilon_{i j}+c_{k}+s \times c_{j k}+\delta_{i j k}+y_{l}+b \times y_{i l}$
$+s \times y_{j l}+\theta_{i j l}+c \times y_{k l}+s \times c \times y_{j k l}+\gamma_{i j k l}$,

where $\mu$ is constant and $s_{j}, c_{k}, s \times c_{j k}, y_{l}, s \times y_{j l}, c \times y_{k l}$ and $s \times c \times y_{j k l}$ are fixed main and interaction effects for the factors rotation starting point (s), cropping system (c) and year (y). The $b_{i}$ is the random effect for block $i$, and $\varepsilon_{i j}$ and $\delta_{i j k}$ are random main plot and subplot error effects, all mutually independent with variances $\operatorname{var}\left(b_{i}\right)=\sigma_{b}^{2}, \operatorname{var}\left(\varepsilon_{i j}\right)=\sigma_{\varepsilon}^{2}$, and $\operatorname{var}\left(\delta_{\mathrm{ijk}}\right)=$ $\sigma^{2}$. The $b \times y_{i l}$ represents the random time-specific contribution for block $i$, and $\theta_{i j l}$ and $\gamma_{i j k l}$ represent random time-specific main plot and subplot error effects (Gumpertz and Brownie 1993). As shoot DW was observed only in 2002, it was analyzed by using a statistical model of traditional split-plot design. In the plant overwintering assessments, most of the 30 plants within the plots were undamaged. Therefore it was considered sufficient to analyze the winter damage as a plotwise percentage of no damage in plants. An arcsine transformation was applied to the percentage of no winter damage to normalize the data for the statistical analysis. 
Vol. 17 (2008): 88-101.

For all the models mentioned above, REML was used as an estimation method and degrees of freedom were calculated by the Kenward-Roger method (Kenward and Roger 1997). The models were fitted using the MIXED procedure of SAS version 9.1.3 (SAS Institute, Cary, NC, USA). Pairwise comparisons were performed by twosided t-type tests. The model assumptions were checked using appropriate graphs and tests. Due to an experimental error that had occurred during the set-up of the experiment in 1981 or 1982, two experimental plots (Cropping system B/rotation point 1/Block 1 and Cropping system D/rotation point 1/Block 1) were excluded from the data and subsequent statistical analyses (see Vestberg et al. 2002).

\section{Results}

\section{Soil properties}

Without peat amendment, the level of soil $\mathrm{C}_{\text {org }}$ was low. The OCS rotation $\mathrm{D}$ exhibited only 0.3 per- centage points higher $\mathrm{C}_{\text {org }}$ than the $\mathrm{CCS}$ rotation $\mathrm{A}$ (Table 2). However, peat amendment raised $\mathrm{C}_{\text {org }}$ by about 2 percentage points the year after application. In contrast, peat amendment decreased $\mathrm{pH}$, soluble $\mathrm{P}$, and $\mathrm{Ca}$. The cropping system did not affect $\mathrm{pH}$, extractable $\mathrm{Ca}$ and $\mathrm{Mg}$, but $\mathrm{P}$ and $\mathrm{K}$ were at higher levels in the CCS than in the OCSs (Table 2). Electrical conductivity and the amounts of extractable $\mathrm{NO}_{3}-\mathrm{N}$ and $\mathrm{NH}_{4}-\mathrm{N}$ were extremely low, reflecting a normal situation after the growing season.

\section{Winter damage}

The cropping system did not affect the proportion of overwintered healthy plants, but peat amendment significantly increased it (Table 3, Fig 2). Only $2.7 \%$ (29 plants out of 960 ) of the plants died during the experiment. Irrespective of the cropping system, after the first winter no plants had died on the plots amended with peat. After the second winter, a few plants had died on the peat-amended plots, but still fewer than on the unamended plots.

Table 2. Soil properties from conventional (A) and organic (D) rotations without and with peat amendment measured in 2001 (mean $\pm \mathrm{SD}, n=6$ and 3 for unamended and peat-amended, respectively).

\begin{tabular}{|c|c|c|c|c|}
\hline Soil property & $\begin{array}{c}\text { Conventional } \\
\text { No } \\
\text { amendment }\end{array}$ & $\begin{array}{c}\text { Conventional } \\
\text { Peat- } \\
\text { amended }\end{array}$ & $\begin{array}{c}\text { Organic } \\
\text { No } \\
\text { amendment }\end{array}$ & $\begin{array}{c}\text { Organic } \\
\text { Peat- } \\
\text { amended }\end{array}$ \\
\hline $\mathrm{C}_{\text {org }}(\%)$ & $2.0 \pm 0.1$ & $3.6 \pm 0.3$ & $2.3 \pm 0.2$ & $4.3 \pm 0.2$ \\
\hline $\begin{array}{l}\text { Electrical conductivity } \\
\left(10 \times \mathrm{mS} \mathrm{cm}^{-1}\right)\end{array}$ & $1.9 \pm 0.3$ & $1.2 \pm 0.2$ & $1.3 \pm 0.3$ & $0.9 \pm 0.1$ \\
\hline $\mathrm{pH}$ (water) & $6.4 \pm 0.2$ & $5.7 \pm 0.1$ & $6.5 \pm 0.5$ & $5.6 \pm 0.1$ \\
\hline \multicolumn{5}{|c|}{ Extractable nutrients ( $\mathrm{mg} \mathrm{l}^{-1}$ soil) } \\
\hline $\mathrm{P}$ & $28.9 \pm 6.5$ & $22.0 \pm 2.0$ & $20.3 \pm 7.9$ & $13.3 \pm 1.2$ \\
\hline K & $84.7 \pm 3.6$ & $82.9 \pm 3.1$ & $63.9 \pm 24.2$ & $61.3 \pm 6.8$ \\
\hline $\mathrm{Ca}$ & $1772 \pm 213$ & $1533 \pm 32$ & $1980 \pm 738$ & $1537 \pm 47$ \\
\hline $\mathrm{Mg}$ & $245 \pm 14$ & $236 \pm 9$ & $251 \pm 23$ & $236 \pm 3$ \\
\hline $\mathrm{NO}_{3}-\mathrm{N}$ & $0.6 \pm 0.2$ & $0.3 \pm 0.1$ & $0.6 \pm 0.1$ & $0.2 \pm 0.03$ \\
\hline $\mathrm{NH}_{4}-\mathrm{N}$ & $2.0 \pm 0.2$ & $1.9 \pm 0.2$ & $3.1 \pm 0.2$ & $2.7 \pm 0.1$ \\
\hline
\end{tabular}


Vestberg, et al. Cropping system impact on strawberry fruit yield

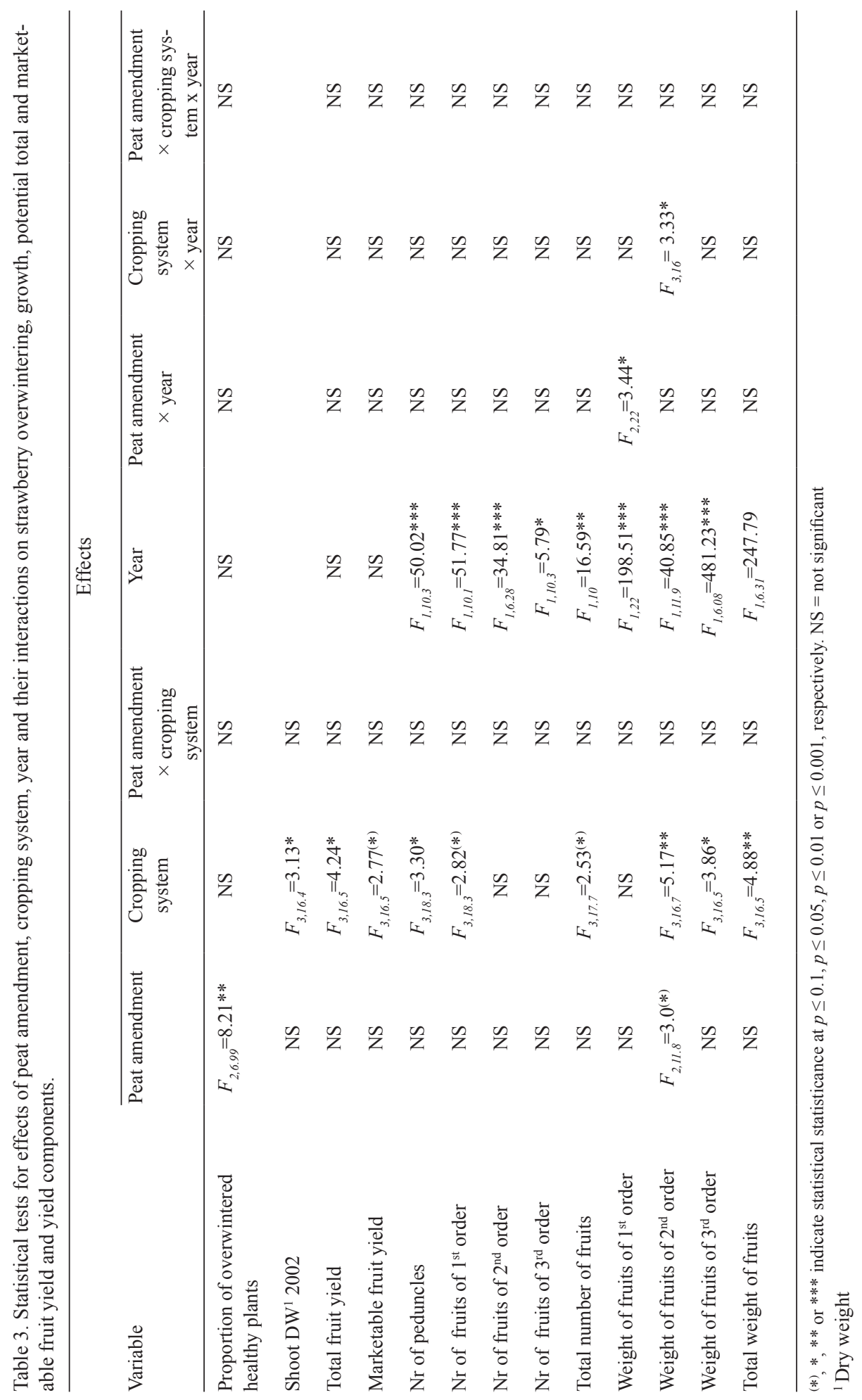


Fig. 2. Effect of cropping system and peat amendment on proportion of healthy and winter damaged (dead + suffering) strawberry plants in May 2001 and 2002. The grey area presents the estimated percentage of healthy plants.
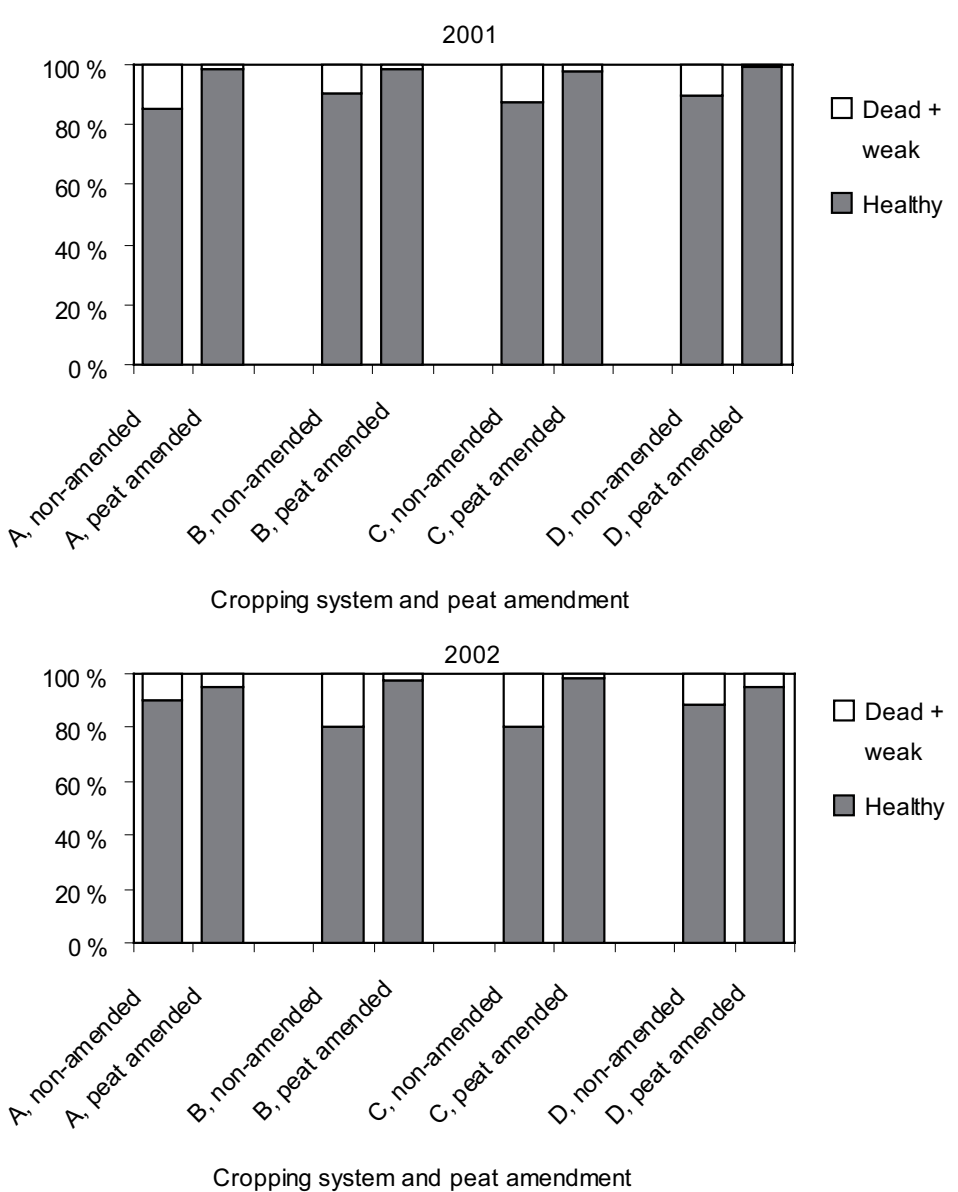

\section{Shoot growth and fruit yield}

The shoot growth was significantly affected by the cropping system but not by peat amendment (Tables 3, 4 and 5). The shoot DW was significantly lower in rotation $\mathrm{A}$ than in rotations $\mathrm{C}$ or D (Table 4). The cropping system affected total fruit yield significantly, but peat amendment did not (Table 3). Compared with CCS rotation A, total yields were significantly higher in the organic systems $\mathrm{C}(p=$ $0.02)$ and $\mathrm{D}(p<0.005)$, but not in $\mathrm{B}(p=0.16)$ (Table 4). In rotation A total fruit yield was $533 \mathrm{~g}$ per plant $(95 \%$ Confidence Interval $(\mathrm{CI})=458-609$ g) and in rotations $\mathrm{C}$ and D $20 \%$ and $27 \%$ higher, respectively. The peat amended plots yielded $678 \mathrm{~g}$ per plant $(95 \% \mathrm{CI}=567-789 \mathrm{~g})$ and non-amended plots $577 \mathrm{~g}$ per plant $(95 \% \mathrm{CI}=498-657 \mathrm{~g})$. Total fruit yield was not affected by the year (Table 3 ). No differences in the interpretation of the results were observed when the data was tested excluding two outliers (2001/rotation point 3/cropping system D/ block 2 and 2002/rotation point / cropping system C/block 1).

The marketable fruit yield was $15 \%$ and $20 \%$ lower than the total fruit yield in 2001 and 2002, respectively. The cropping system tended to affect marketable yield significantly (Table 3). Pairwise comparisons of estimated means showed that marketable yield was significantly lower in A (452 g per plant; $95 \% \mathrm{CI}=390-514 \mathrm{~g})$ than in $\mathrm{D}(550 \mathrm{~g}$ 
Vestberg, et al. Cropping system impact on strawberry fruit yield

Table 4. Effect of cropping system on strawberry shoot dry weight, number of peduncles per strawberry plant and on fruit numbers and fruit fresh weights. For shoot DW, values are estimated means ( $\pm 95 \%$ confidence intervals) of 8 (CCS-A and OCS-B) and 9 (OCS-C and OCS-D) observations. For all other variables, values are estimated means ( $\pm 95 \%$ confidence intervals) of the years 2001 and 2002, 16 (CCS-A and OCS-B) and 18 (OCS-C and OCS-D) observations.

\begin{tabular}{lcccc}
\hline \multirow{2}{*}{ Variable } & \multicolumn{4}{c}{ Cropping system } \\
\cline { 2 - 5 } & CCS (A) & OCS (B) & OCS (C) & OCS (D) \\
\hline Potential total fruit yield & $533.5 \pm 75.9$ & $596.5 \pm 80.7$ & $637.6 \pm 75.9^{*}$ & $675.5 \pm 80.7^{* *}$ \\
Potential marketable fruit yield & $452.0 \pm 62.1$ & $499.6 \pm 66.1$ & $516.0 \pm 62.1$ & $550.0 \pm 66.1^{*}$ \\
Shoot DW & $49.4 \pm 6.6$ & $52.0 \pm 6.9$ & $56.9 \pm 6.6^{*}$ & $58.6 \pm 6.9^{*}$ \\
Nr of peduncles per plant & $10.9 \pm 1.1$ & $11.9 \pm 1.2$ & $12.1 \pm 1.1$ & $13.3 \pm 1.2^{* *}$ \\
Nr of fruits of $1^{\text {st }}$ order per plant & $11.0 \pm 1.2$ & $11.9 \pm 1.3$ & $12.3 \pm 1.2$ & $13.1 \pm 1.3^{*}$ \\
Nr of fruits of $2^{\text {nd }}$ order per plant & $27.5 \pm 3.1$ & $29.1 \pm 3.3$ & $30.5 \pm 3.1$ & $32.0 \pm 3.3^{*}$ \\
Nr of fruits of $3^{\text {rd }}$ order per plant & $26.5 \pm 3.3$ & $27.8 \pm 3.5$ & $29.0 \pm 3.3$ & $31.3 \pm 3.5^{*}$ \\
Total number of fruits per plant & $71.6 \pm 7.9$ & $77.6 \pm 8.6$ & $80.6 \pm 7.9$ & $85.1 \pm 8.6^{*}$ \\
FW $^{2}$ of fruits of $1^{\text {st }}$ order, g & $16.4 \pm 0.7$ & $16.7 \pm 0.7$ & $17.2 \pm 0.7^{*}$ & $16.9 \pm 0.7$ \\
FW $^{2}$ of fruits of $2^{\text {nd }}$ order, g & $8.8 \pm 0.3$ & $9.3 \pm 0.3^{* *}$ & $9.3 \pm 0.3^{* *}$ & $9.3 \pm 0.3^{* *}$ \\
$\quad$ - year 2001 & $9.8 \pm 0.4$ & $10.1 \pm 0.5$ & $10.0 \pm 0.4$ & $9.8 \pm 0.5$ \\
- year 2002 & $7.8 \pm 0.3$ & $8.5 \pm 0.5^{* *}$ & $8.5 \pm 0.4^{* *}$ & $8.8 \pm 0.5^{* * *}$ \\
FW $^{2}$ of fruits of $3^{\text {rd }}$ order, g & $4.9 \pm 0.3$ & $5.1 \pm 0.3^{*}$ & $5.2 \pm 0.3^{*}$ & $5.3 \pm 0.3^{*}$ \\
Mean fruit fresh weight, g & $10.0 \pm 0.4$ & $10.4 \pm 0.4$ & $10.6 \pm 0.4$ & $10.5 \pm 0.4$ \\
\hline
\end{tabular}

Cropping systems marked with *, ** or *** differ from CCS-A at $p=0.05, p=0.01$ or $p=0.001$, respectively. CCS $=$ Conventional cropping system, OCS $=$ organic cropping system. Letters A, B, C and D refer to rotations A $-\mathrm{D}$.

${ }^{1}$ Dry weight. ${ }^{2}$ Fresh weight.

Table 5. Effect of peat amendment on strawberry total and marketable fruit yield, shoot dry weight, number of peduncles per strawberry plant and on fruit numbers and fruit fresh weights. For shoot DW, values are estimated means $( \pm 95 \%$ confidence intervals) of 22 (non-amended) and 12 (peat amended) observations. For all other variables, values are estimated means ( \pm 95\% confidence intervals) of the years 1001 and 2002, 44 (non-amended) and 24 (peat amended) observations.

\begin{tabular}{|c|c|c|}
\hline Variable & Non-amended & Peat-amended \\
\hline Potential total fruit yield, g per plant & $577 \pm 79$ & $678 \pm 111$ \\
\hline Potential marketable fruit yield, g per plant & $473 \pm 64$ & $567 \pm 90$ \\
\hline Shoot DW ${ }^{1)}$ & $53.4 \pm 7.3$ & $55.9 \pm 7.5$ \\
\hline $\mathrm{Nr}$ of peduncles per plant & $11.7 \pm 0.9$ & $12.8 \pm 1.2$ \\
\hline $\mathrm{Nr}$ of fruits of $1^{\text {st }}$ order per plant & $11.7 \pm 0.9$ & $12.8 \pm 1.3$ \\
\hline $\mathrm{Nr}$ of fruits of $2^{\text {nd }}$ order per plant & $28.8 \pm 2.9$ & $31.9 \pm 4.0$ \\
\hline $\mathrm{Nr}$ of fruits of $3^{\text {rd }}$ order per plant & $27.1 \pm 2.7$ & $31.8 \pm 3.7$ \\
\hline Total number of fruits per plant & $75.2 \pm 6.7$ & $85.8 \pm 9.0$ \\
\hline $\mathrm{FW}^{2)}$ of fruits of $1^{\text {st }}$ order, $\mathrm{g}$ & $16.5 \pm 0.7$ & $17.4 \pm 1.0$ \\
\hline - year 2001 & $18.4 \pm 0.8$ & $19.7 \pm 1.0 *$ \\
\hline - year 2002 & $14.5 \pm 0.8$ & $15.1 \pm 1.0$ \\
\hline $\mathrm{FW}^{2)}$ of fruits of $2^{\text {nd }}$ order, $\mathrm{g}$ & $9.0 \pm 0.3$ & $9.6 \pm 0.5^{*}$ \\
\hline $\mathrm{FW}^{2)}$ of fruits of $3^{\text {rd }}$ order, $\mathrm{g}$ & $5.1 \pm 0.3$ & $5.1 \pm 0.4$ \\
\hline Mean fruit FW, $g$ & $10.2 \pm 0.4$ & $10.8 \pm 0.6$ \\
\hline
\end{tabular}

Means of peat amended marked with $*, * *$ or $* * *$ differ from non-amended at $p \leq 0.05, p \leq 0.01$ or $p \leq 0.001$, respectively.

${ }^{1)}$ Dry weight. ${ }^{2)}$ Fresh weight. 
Vol. 17 (2008): 88-101.

per plant; 95\% CI $=484-616 \mathrm{~g})(p=0.01)(\mathrm{Ta}-$ ble 4$)$. After omitting the same two outliers as for total yield, there was also significantly higher marketable yield in rotation C compared to A ( $p<$ 0.01 ). Peat amendment did not affect marketable yield (Table 3, Table 5) but, by omitting the outliers, a significant difference $(p=0.04)$ between peat amended $(567 \mathrm{~g}$ per plant; $95 \% \mathrm{CI}=495-639$ g) and unamended (471.6 g per plant; $95 \% \mathrm{CI}=$ 420-523) was observed.

\section{Yield components}

The cropping system affected significantly the numbers of peduncles per strawberry plant (Tables 3 and $4)$. The estimated mean number of peduncles per plant was lower $(p<0.01)$ in CCS rotation A (10.9; $95 \% \mathrm{CI}=9.8-12.1)$ than in OCS rotation D (13.3; $95 \% \mathrm{CI}=12.1-14.6 \mathrm{~g}$ ) (Table 4). Testing the data without one outlier (2002/rotation point 3/cropping system $\mathrm{C} /$ block 1 ) revealed a significant difference also between $\mathrm{A}$ and $\mathrm{C}(p=0.02)$. The impact of the cropping system on the total number of fruits as well as on the $1^{\text {st }}, 2^{\text {nd }}$ and $3^{\text {rd }}$ order fruits was also close to significant (Table 3). In fact, pair wise comparisons using the t-test showed a significantly higher number of fruits in rotation D than in rotation A (Table 4). Peat amendment did not significantly affect the number of fruits (Tables 3 and 5).

The cropping system affected significantly all the fruit weights measured except the weight of $1^{\text {st }}$ order fruits (Tables 3 and 4). The lowest mean fruit weight was observed in CCS rotation A and the highest in OCS rotation D (Table 4). Significant differences in mean fruit weights were obtained between $\mathrm{A}$ and $\mathrm{C}(p<0.005)$ and between A and D $(p$ $=<0.01)$. After omitting one outlier (2002/rotation point 3/cropping system $\mathrm{D} /$ block 2 ) from the data, the difference A-B was also significant $(p=0.02$ ). The weight of $2^{\text {nd }}$ order fruits showed a significant interaction between year and cropping system (Table 3). In 2001, no significant difference in fruit weight was observed between systems, but in 2002 the fruit weight was higher in all organic rotations than in the conventional rotation (Table 4).
Peat amendment tended to affect the weight of $1^{\text {st }}$ order fruits in $2001(p=0.06)$, but not in $2002(p$ $=0.36$ ). The $2^{\text {nd }}$ order fruit weight was not affected significantly by peat amendment according to the F-test for the main effect, but the pair wise t-test comparing the starting point amended with peat to the mean of the two unamended starting points showed an effect ( $p=0.03)$ (Table 5).

All yield components were significantly affected by the year (Table 3 ). The number of peduncles, fruits of $1^{\text {st }}, 2^{\text {nd }}$ and $3^{\text {rd }}$ order and the total number of fruits per plant, were all higher in 2002 than in 2001. In contrast to this, the fruit weights of all orders and the mean fruit weight were lower in 2002 than in 2001.

\section{Discussion}

\section{Impact of cropping system}

The shoot growth and total and marketable fruit yields were all significantly higher in the organic cropping system $\mathrm{D}$ than in the conventional system A. This result is in contrast with most studies on strawberry. In California, a three-year on-farm study of strawberry undergoing conversion to organic production, the yield in OCS was 39\%, 30\% and $28 \%$ lower than in CCS for the $1^{\text {st }}, 2^{\text {nd }}$ and $3^{\text {rd }}$ year of conversion, respectively (Gliessman et al. 1996). In a greenhouse study, Palomäki et al. (2002) observed a $25 \%$ lower strawberry yield in the organic than in the conventional system, but this difference was not statistically significant. However, field studies in Estonia showed higher yields of some cultivars on near-organic plots fertilized with FYM in comparison with conventional plots fertilized with mineral fertilizers (Kahu and Klaas 2005).

The number of peduncles and the number of fruits $\left(1^{\text {st }}, 2^{\text {nd }}\right.$ and $3^{\text {rd }}$ order and total $)$ per strawberry plant were all higher in the organic system $\mathrm{D}$ than in the conventional system A. Similarly, the weight of all fruits as well as the mean fruit weight, were also higher in the organic than in the conventional cropping system. This result is in contrast with the 
Vestberg, et al. Cropping system impact on strawberry fruit yield

findings of Rhainds et al. (2002) who observed lower total numbers of strawberry fruits in OCSs than in CCSs with similar mean fruit weights in the two management systems. In another Californian study, Gliessman et al. (1996) concluded that lower strawberry yields in OCS than in CCS during the first year was due to the production of fewer berries. In the second and third year the berries were not only fewer but also smaller. In our study, it can be concluded that the higher yield potential in the OCS than in CCS was due to larger plants and greater numbers of berries as well as somewhat bigger berries. The number of berries per plant mainly determines the fruit yield, because of a strong positive correlation between these two characteristics (Lacey 1973).

\section{Impact of organic amendment}

Peat amendment did not significantly increase total yield, but marketable yield was significantly increased due to peat amendment when two suspicious outliers were omitted from the data. In studies with other crops, positive effects from the use of peat for amendment of heavy soils have been observed. According to Larpes (1978), cereal grain yields were on average $70 \%$ higher one year after application and still 5\% higher after 10 years. Pietola and Tanni (2003) also found on average a $500 \mathrm{~kg} \mathrm{ha}^{-1}$ increase in cereal grain yield due to peat application. The most positive impacts of peat amendment have been observed on silty clay where the proportion of clay is increasing in the subsoil (Larpes 1978, Kytö et al. 1983).

Organic amendments other than peat have had relatively little effect on strawberry growth and yield. Kramer (1970) observed a significant 3-12\% yield increase after green manuring, but Encke (1988) found no impact of the type of manure applied or the rate of application on generative and vegetative characters of the strawberry. Different organic amendments, however, increased the fruit yields of strawberry by more than $50 \%$ in studies of Türemis (2002) and Wang and Lin (2002). In contrast to these studies, Svensson (2002) found increased vegetative growth of strawberry after application of composted FYM, but at the expense of yield.

In northern latitudes with a long winter strawberry plants can suffer considerably from winter damage which can act as a triggering factor for black root rot (Kukkonen et al. 2004). In this study, however, the strawberry plants overwintered very well and only few plants died during the two winters of the experiment. Peat amendment further decreased the percentage of strawberry plants injured or killed by winter damage. This might have been due to the higher $\mathrm{C}_{\text {org }}$ of the soil and subsequent improvement of the physical properties of the soil. On heavy soils, strawberry plants are commonly lifted up vertically due to frost in the surface soil, especially during and after the first winter. This phenomenon easily results in root injuries. In the peat-amended plots, the strawberry plants rose very little compared with the other plots.

\section{Role of soil nutrients}

The amounts of extractable $\mathrm{P}$ and $\mathrm{K}$ were higher in the CCS than in OCS. This is in agreement with earlier reports from this experiment (Vestberg et al. 2002). Despite lower amounts of extractable soil nutrients and only marginally increased $\mathrm{C}_{\text {org }}$, total yield of strawberry was higher in the organic rotation $\mathrm{D}$ than in the conventional rotation A. However, the amounts of extractable nutrients in soil were quite high in both systems, indicating that in neither system were nutrients a limiting factor for strawberry growth and yield. It can therefore be concluded that the reasons for the higher fruit yields in OCS than in CCS could rather be found in the physical or biological than in the chemical properties of soil. It is not clear, however, how much of the cropping system effect was a result of the long-term cropping history and how much was a short-term effect due to the application of composted manure to the organic plots in 2000. Obviously, in 2001 and 2002 there was still substantial mineralisation of $\mathrm{N}$ from composted manure applied in 2000. Some strawberry studies have shown considerable increases in strawberry 
Vol. 17 (2008): 88-101.

fruit yields after application of composts or manures (Türemis 2002, Wang and Lin 2002).

The strawberry experiment was established with the intention of giving similar total amounts of nutrients to the conventional and organic systems, but it is not possible to know how much nutrients really were available to the plants in the two contrasting systems. The nutrients were readily available in the conventional system but slowly available in the organic system. In field-grown strawberry in northern latitudes, the yield is rarely affected by fertilization treatments (Hoppula et al. 2001, Moor et al. 2004, Lanauskas et al. 2006). This is probably due to good basic soil fertility, since supplying nutrients to strawberry will likely be ineffective if the soil nutrient pool is already sufficient to meet plant needs (Tagliavini et al. 2004). Strawberry removes less nutrients from the soil than most other crops. MacNaeidhe (2005) estimated that perennial strawberry yielding 10-15 tons per ha in Ireland removed $38 \mathrm{~kg} \mathrm{~N}, 5 \mathrm{~kg} \mathrm{P}$ and $44 \mathrm{~kg} \mathrm{~K}$ from soil per year. The corresponding numbers were $128 \mathrm{~kg} \mathrm{~N}, 16 \mathrm{~kg} P$ and $21 \mathrm{~kg} \mathrm{~K}$ for strawberry yielding 46 tons per ha in Finland (Tagliavini et al. 2004). We obtained mean fruit yields of $533 \mathrm{~g}$ per plant and $675 \mathrm{~g}$ per plant for CCS rotation A and OCS rotation D, respectively, which corresponds to 13.3 tons per ha and 16.9 tons per ha in single-row cultivation of strawberry with 25000 plants per ha. Therefore, the nutrients given to the soil in the CCS and the OCSs were adequate for the needs of strawberry (see Table 1) at yield levels of around 15 tons per ha.

In a situation with moderate or good soil fertility, the biological properties of the soil can be of considerable importance for strawberry growth and yield. In this study, the slightly higher amounts of $\mathrm{NH}_{4}-\mathrm{N}$ in the organic plots than in the conventional plots after the growing season indicate higher microbial activity and nutrient mineralization due to the relative recent application of FYM to these plots. Elevated $\mathrm{C}_{\text {org }}$ also affects several other soil properties like water holding capacity, microbial biomass, enzyme activities, numbers of earthworms, etc. which all have an impact on soil quality, nutrient cycling and plant growth. Since we measured $\mathrm{C}_{\text {org }}$ only at the end of the 2001 season, we cannot know its temporal variation which may have a direct impact on $\mathrm{N}$ availability for the growing strawberry plants.

Organic strawberry production is still quite low worldwide. A survey in the EU and neighbouring countries showed that the percentage of area in organic strawberry production varied between 0.5 and 6 (Steffek et al. 2004). This study showed that yield of strawberry can be higher in organic than in conventional production. Before the reasons behind this result can be fully understood, however, a more comprehensive study of soil properties is needed with particular emphasis on the biological properties of soil.

Acknowledgements. This study was financed by the Ministry of Agriculture and Forestry in Finland and by a special grant from MTT Agrifood Research Finland. The field experiment was carried out at MTT Agrifood Research Finland, Laukaa. We are grateful to Mr Mauri Räkköläinen who was responsible for the establishment and subsequent management of the field experiment. Particularly, we thank Mr Olli Reinikainen at Vapo Oy for providing us with the peat for the experiment. We also wish to thank Ms Sevastiana Ruusamo, M.A., for the valuable revision of the English text.

\section{References}

Daugaard, H., 1999. Cultural methods for controlling Botrytis cinerea Pers. in strawberry. Biological Agriculture and Horticulture 16: 351-361.

Encke, O. 1988. Einfluß unterschiedlicher organischer Düngungstoffe und Fruchtfolgen auf den Ertrag der Erdbeersorte 'Red Gauntlet'. Archiv für Gartenbau 36: 423-431.

Gesslein, S. 2001. Cropping system, plant nutrition and soil fertility - 18 years of results on a previously exhausted soil. Kungliga Skogs- och Lantbruksakademiens Tidskrift 140: 3-77. (In Swedish with extended English summary).

Gliessman, S.R., Werner, M.R., Allison, J. \& Cochran, J. 1996. A comparison of strawberry plant development and yield under organic and conventional management on the central California coast. Biological Agriculture and Horticulture 12: 327-338.

Gumpertz, M.L. \& Brownie, C. 1993. Repeated measures in randomized block and split-plot experiments. Canadian Journal of Forest Research 23: 625-639.

Hoppula, K., Salo, T. \& Pulkkinen, J. 2001. Nitrogen uptake and allocation in strawberry. In: Tahvonen, R., Suojala, T. \& Sironen, L. (Eds.). Horticultural Production Adapt- 
Vestberg, et al. Cropping system impact on strawberry fruit yield

ed to Seasonal Growing Conditions. Maatalouden Tutkimuskeskuksen Julkaisuja, Sarja A 91: 19-26. (In Finnish with English summary)

Kahu, K. \& Klaas, L. 2005. Strawberry cultivars in the traditional and organic growing. Transactions of the Estonian Agricultural University, Agronomy 220: 114-116.

Kenward, M.G. \& Roger, J.H. 1997. Small sample inference for fixed effects from restricted maximum likelihood. Biometrics 53: 983-997.

Korva, J. \& Varis, E. 1990. Conventional and organic cropping systems at Suitia. II: crop growth and yield. Journal of Agricultural Science in Finland 62: 309- 319.

Kramer, S. 1970. Der Einfluß der Vorkultur und der Tiefe der Bodenvorbereitung auf Ertrag und Fruchtgröße der Erdbeere. Archiv für Gartenbau 18: 393-405.

Kukkonen, S., Vestberg, M., Tuovinen, T. \& Järvinen O. 2004. Influence of soil and planting material on the development of strawberry root rot. Acta Horticulturae 635: 19-24.

Kytö, M., Sipilä, K. \& Thun, R. 1983. Weakly decomposed peat for soil improvement and litter. Technical Research Centre of Finland. Research Notes 240. 46 p.

Lacey, C.N.D. 1973. Phenotypic correlations between vegetative characters and yield components in strawberry. Euphytica 22: 546-554.

Lanauskas, J., Uselis, N., Valiuškaitè, A. \& Viškelis, P. 2006. Effect of foliar and soil applied fertilizers on strawberry healthiness, yield and berry quality. Agronomy Research 4: 247-250.

Larpes, G. 1978. Torv som jordförbättringsmedel, vårsädesskördar på mjälleror. Nordisk Jordbruksforskning 61: 178-179.

Li, H., Parent, L.E., Karam, A. \& Tremblay, C. 2004. Potential of Sphagnum peat for improving soil organic matter, water holding capacity, bulk density and potato yield in a sandy soil. Plant and Soil 265: 355-365.

MacNaeidhe, F. 2005. A cream of a crop. Organic Matters. (http//www.organicmattersmag.com/articles/a_cream_ of_a_crop.php)

Mäder, P., Fließbach, A., Dubois, D., Gunst, L., Fried, P. \& Niggli, U. 2002. Soil fertility and biodiversity in organic farming. Science 296: 1694-1697.

Moor, U., Karp, K. \& Põldma, P. 2004. Effect of mulching and fertilization on the quality of strawberries. Agriculture and Food Science 13: 256-267.

Palomäki, V., Mansikka-aho, A.-M. \& Etelämäki, M. 2002. Organic fertilization and cultivation technique of strawberry grown in greenhouse. Acta Horticulturae 567:
597-599.

Pietola, L. \& Tanni, R. 2003. Response of seedbed physical properties, soil $\mathrm{N}$ and cereal growth to peat application during transition to conservation tillage. Soil and Tillage Research 74: 65-79.

Reeves, D.W. 1997. The role of soil organic matter in maintaining soil quality in continuous cropping systems. Soil and Tillage Research 43: 131-167.

Rhainds, M., Kovach, J., English-Loeb, G. 2002. Impact of strawberry cultivar and incidence of pests on yield and profitability of strawberries under conventional and organic management systems. Biological Agriculture and Horticulture 19:333-353.

Stanhill, G. 1990. The comparative productivity of organic agriculture. Agriculture, Ecosystems and Environment 30: 1-26.

Steffek, R., Bylemans, D., Nikolova, G., Carlen, C., Faby, R., Daugaard, H., Tirado, L., Pommier, J.J., Tuovinen, T., Nyerges, K., Manichi, L., MacNaeidhe, F., Trandem, N., Wander, J., Evenhuis, B., Labanowska, B., Bielenin, A., Svensson, B., Fitzgerald, J. \& Blümel, S. 2004. Status of sustainable strawberry production within Europe. Acta Horticulturae 649: 247-250.

Svensson, B. 2002. Organic growing of strawberries, with control of insects and mulching/fertilisation. Acta horticulturae 567: 419-422.

Tagliavini, M., Baldi, E., Nestby, R., Raynal-Lacroix, C., Lieten, P., Salo, T., Pivot, D., Lucchi, P.L., Baruzzi, G. \& Faedi, W. 2004. Uptake and partitioning of major nutrients by strawberry plants. Acta Horticulturae 649: 197-200.

Tuovinen, T. \& Parikka, P. 1997. Monitoring strawberry pests and diseases: a method to estimate yield losses. Acta Horticulturae 439: 941-946.

Türemis, N. 2002. The effects of different organic deposits on yield and quality of strawberry cultivar Dorit (216). Acta Horticulturae 567: 507-510.

Von Post, L. 1922. Sveriges geologiska undersöknings torvinventering och några av dess hittills vunna resultat. Svenska mosskulturföreningens Tidskrift 36: 1-27.

Vestberg, M. Kukkonen, S., Saari, K., Uosukainen, M., Palojärvi, A., Tuovinen, T., Vepsäläinen, M. \& Niemi, M. 2002. Cropping system impact on soil quality determinants. Agricultural and Food Science in Finland 11: 311-328.

Wang, S.Y. \& Lin, S-S. 2002. Composts as soil supplement enhanced plant growth and fruit quality of strawberry. Journal of Plant Nutrition 25: 2243-2259. 
Vol. 17 (2008): 88-101.

\title{
SELOSTUS
}

\section{Viljelyjärjestelmän ja turpeenlisäyksen vaikutus mansikan kasvuun ja satoisuuteen}

\author{
Mauritz Vestberg, Sanna Kukkonen, Hanna Kuru, Kaisa Saari ja Timo Hurme \\ MTT (Maa- ja elintarviketalouden tutkimuskeskus)
}

Pelto- ja puutarhakasvien sato on yleensä ollut vähäisempi luonnonmukaisessa viljelyssä kuin tavanomaisessa. Syynä on luomuviljelyyn hyväksyttyjen lannoitusaineiden (esim. lannat, kompostit, viherlannoitus) vähäisempi ravinnesisältö, sekä rajoitetut keinot rikkakasvien, kasvitautien ja tuholaisten torjumiseksi. Luomuviljelyssä käytetyt menetelmät kuitenkin todennäköisesti ylläpitävät pellon monimuotoisuutta sekä suojaavat peltomaata eloperäisen aineksen hävikiltä ja eliötoiminnan heikentymiseltä.

Tässä julkaisussa verrataan mansikan kasvua ja sadontuottokykyä pellossa, jossa on takana 18 vuoden luonnonmukainen tai tavanomainen viljelyhistoria. Tämä MTT:n koekenttä sijaitsi hiesumaalla Laukaassa, KeskiSuomessa. Koealueella oli vuosina 1982-1993 viljelty viljakasveja tavanomaisin menetelmin sekä omavaraisen, ulkomaisista tuotantopanoksista riippumattoman, viljelyn periaattein. Käytännössä omavaraisen viljelyn menetelmät olivat hyvin lähellä luomuviljelyä. Vuosina 1994-1999 omavaraisesti viljellyt ja osa tavanomaisesti viljellyistä ruuduista siirrettiin luomuviljelyyn. Koeruutuja oli yhteensä 36 ja koeasetelmana osaruutukoe, jossa osaruutuja oli neljä (1 tavanomainen ja 3 luonnonmukaista viljelytapaa), pääruutuja kolme (viljelykierto aloitettu 3 eri kohtaa) ja toistoja kolme. Alkukesällä 2000 yhdelle pääruuduista, eli rinnakkaisista viljelykierroista, levitettiin $500 \mathrm{~m}^{3} \mathrm{ha}^{-1}$ maanparannusturvetta. Kesäkuussa koealueelle istutettiin mansikkakasvusto mustalla muovilla katettuihin ja tihkukastelujärjestelmällä varustettuihin harjuihin. Tavanomaisen viljelyhistorian omaaville ruuduille annettiin kivennäislannoitus perustettaessa ja liuoslannoitusta kasvukausien aikana tihkukastelujärjestelmän kautta. Luomuviljelyhistorian omaaville ruuduille annettiin karjanlantakompostia perustettaessa ja vettä tihkukasteluna.

Mansikan talvehtiminen arvioitiin ja sato määritettiin kukkavana-analyysin avulla vuosina 2001 ja 2002. Loppukesällä 2002 määritettiin myös mansikan lehvästömassa. Syksyllä 2001 määritettiin liukoisten ravinteiden pitoisuudet sekä orgaanisen aineksen määrä maassa. Luonnonmukaisin menetelmin viljellyssä maassa mansikkasadot olivat suurempia kuin tavanomaisen viljelyhistorian omaavassa maassa. Myös mansikan lehvästön kasvu oli rehevintä luomuviljellyssä maassa. Luomuviljely vaikutti maan ravinnetilaan siten, että fosforiluku laski hyvästä tyydyttävään ja kaliluku välttävästä huononlaiseksi, mutta ammoniumtypen määrä lisääntyi (tavanomaisesti viljellyssä 40 ja luomuviljellyssä maassa $60 \mathrm{~kg} / \mathrm{ha}$ ). Maanparannusturve ei selvästi vaikuttanut mansikkasatoihin, vaikka se paransikin mansikan talvehtimista. Turve nosti huomattavasti koealueen lähtökohtaisesti alhaista humuspitoisuutta, luomuviljely puolestaan nosti sitä hieman. Tulosten perusteella voidaan todeta, että luonnonmukaisella viljelyllä voidaan saada aikaan hiesupellossa edullisia muutoksia, jotka näkyvät monivuotisten puutarhakasvien sadontuottokyvyssä. Mansikan kasvuun ja satoisuuteen on saattanut pitkäaikaisen viljelyhistorian lisäksi vaikuttaa erot mansikkakasvuston lannoituskäytännössä (luomussa karjanlanta, tavanomaisessa rakeinen ja liuoslannoitus). 